\title{
Correction to: Laxative effect of repeated Daiokanzoto is attributable to decrease in aquaporin-3 expression in the colon
}

\author{
Risako Kon ${ }^{1} \cdot$ Miho Yamamura $^{2} \cdot$ Yukari Matsunaga ${ }^{3} \cdot$ Hiroshi Kimura $^{3} \cdot$ Moe Minami $^{3} \cdot$ Saki Kato $^{3}$. \\ Nobutomo Ikarashi ${ }^{3} \cdot$ Kiyoshi Sugiyama $^{4}$
}

Published online: 2 April 2019

(c) The Author(s) 2019

\section{Correction to: Journal of Natural Medicines (2018) 72:493-502 https://doi.org/10.1007/s11418-018-1174-1}

The article Laxative effect of repeated Daiokanzoto is attributable to decrease in aquaporin-3 expression in the colon, written by Risako Kon, Miho Yamamura, Yukari Matsunaga, Hiroshi Kimura, Moe Minami, Saki Kato, Nobutomo Ikarashi, Kiyoshi Sugiyama, was originally published electronically on the publisher's internet portal (currently SpringerLink) on 27 January 2018 without open access.

With the author(s)' decision to opt for Open Choice the copyright of the article changed on 10 April 2019 to (C) The Author(s) [Year] and the article is forthwith distributed under the terms of the Creative Commons Attribution 4.0 International License (http://creativecommons.org/licenses/ by/4.0/), which permits use, duplication, adaptation, distribution and reproduction in any medium or format, as long as you give appropriate credit to the original author(s) and the source, provide a link to the Creative Commons license and indicate if changes were made.

The original article can be found online at https://doi.org/10.1007/ s11418-018-1174-1.

Nobutomo Ikarashi

ikarashi@hoshi.ac.jp

Kiyoshi Sugiyama

sugiyama@hoshi.ac.jp

1 Global Research Center for Innovative Life Science, Hoshi University, Tokyo, Japan

2 Division of Applied Pharmaceutical Education and Research, Hoshi University, Tokyo, Japan

3 Department of Clinical Pharmacokinetics, Hoshi University, 2-4-41 Ebara, Shinagawa-ku, Tokyo 142-8501, Japan

4 Department of Functional Molecular Kinetics, Hoshi University, 2-4-41 Ebara, Shinagawa-ku, Tokyo 142-8501, Japan
Open Access This article is distributed under the terms of the Creative Commons Attribution 4.0 International License (http://creativecommons.org/licenses/by/4.0/), which permits unrestricted use, distribution, and reproduction in any medium, provided you give appropriate credit to the original author(s) and the source, provide a link to the Creative Commons license, and indicate if changes were made.

The original article was corrected.

Publisher's Note Springer Nature remains neutral with regard to jurisdictional claims in published maps and institutional affiliations. 